\title{
A Câmara e o mercado. Os trabalhadores da Praça do Mercado do Rio de Janeiro e suas relações com a municipalidade no século XIX
}

\section{Juliana Barreto Farias*}

Resumo: Neste artigo, procuro discutir a relação da municipalidade do Rio de Janeiro com os trabalhadores - especialmente aqueles identificados como locatários ou arrendatários de bancas - da Praça do Mercado do Rio de Janeiro, principal centro de abastecimento de gêneros de primeira necessidade no período oitocentista. Para tanto, examino em detalhes as disputas travadas entre dois locatários da Praça - Domingos José Sayão, liberto africano de "nação calabar", e Antonio Joaquim Franco, "cidadão brasileiro" - pela posse de uma banca de peixe, em 1846. Nesse percurso, tanto será possível avaliar quem estava "habilitado" a ocupar - e efetivamente ocupava - os diferentes espaços de venda no interior do mercado como também acompanhar as relações, igualmente diferenciadas, que esses pequenos negociantes mantinham com fiscais, agentes municipais e vereadores.

Palavras-chave: Rio de Janeiro - Câmara Municipal - Praça do Mercado - pequenos comerciantes - africanos - "cidadãos brasileiros"

Abstract: In this article, I discuss the relationship of the municipality of Rio de Janeiro with the workers - especially those identified as renters or tenants of stalls - the Praça do Mercado (literally, Market Square) in Rio de Janeiro, the main supply center staples during the eighteenth century. Therefore, I examine in detail the disputes waged between two tenants Square - Domingos José Sayão, freed African "nação" calabar and Joaquim Antonio Franco, "Brazilian citizen" - for possession of a fish stall in 1846. Along the way, both will be possible to assess who was "enabled" to occupy - and effectively occupied - the different sales areas within the market, as well as follow the links, also differentiated these small dealers had with tax, municipal officials and councilors.

Keywords: Rio de Janeiro - City Hall - Market Square - small traders - Africans - "Brazilian citizens"

* Universidade Federal da Bahia 
No Rio de Janeiro, desde pelo menos meados do século XVII, negras de tabuleiro e vendedores de peixe reuniam-se à beira-mar, nas proximidades do terreiro do Ó, mais tarde chamado de Largo do Paço. ${ }^{1}$ Como portas de entrada da cidade, essas áreas litorâneas, conhecidas como praias de marinha, constituíam pontos centrais para o pequeno comércio de pescado e outros gêneros que vinham das lavouras do Recôncavo da Guanabara e de locais mais distantes. Administrados pelo Senado da Câmara, só podiam ser ocupadas por quem tivesse licenças e pagasse foros anuais. ${ }^{2}$ Entretanto, novas bancas e quitandas iam se juntando num ritmo acelerado e desordenado. Para contê-las, os senadores promoviam reformas, limitavam os espaços para as trocas e chegavam mesmo a tentar expulsar os pequenos comerciantes. Especialmente perto da Alfândega, entre a rua do Mercado e o cais das Marinhas, onde foi se formando um pequeno e ruidoso mercado - 0 "Mercado da Praia do Peixe"3.

Com o seu contínuo crescimento, o vice-rei Luiz de Vasconcellos ordenou, em 1789, que as barracas de peixe fossem reconstruídas com regularidade e simetria. Ainda assim, a "algazarra" dos vendedores, a lama e os restos de frutas, legumes e peixes amontoados ali não deixavam de desagradar autoridades e moradores da capital. Alguns diziam que o "vozerio" era tal que perturbava as sessões no Senado. ${ }^{4}$ Mesmo com protestos de lado a lado e as determinações para que fossem removidos para outro local, um novo mercado só começou a ser construído na década de 1830.5

Com projeto do arquiteto francês Grandjean de Montigny, as obras do edifício da Praça do Mercado, também chamada de Mercado da Candelária, iniciaram-se nos primeiros meses de 1835 , mas só foram totalmente concluídas em $1841 .^{6}$ Ocupando todo um quarteirão da freguesia da Candelária, o local ficou internamente dividido em três áreas: o centro, destinado para venda de hortaliças, legumes, aves e ovos; o lado do mar, para peixe fresco, seco e salgado; e o lado da rua (voltado para a rua do Mercado e para o Largo do Paço), para cereais, legumes, farinha e cebolas. ${ }^{7} \mathrm{Na}$ Praça das Marinhas, em frente à doca contígua ao mercado,

1 Inicialmente terreiro do Ó - e depois da Polé -, a área ficou conhecida como terreiro do Carmo quando ali construíram a igreja e o convento dos carmelitas. Mais tarde, foi chamada de Largo do Paço e, depois, de praça d. Pedro II. Com a proclamação da República, ganhou a denominação de Praça XV de Novembro, nome que continua até hoje. Cf.: GERSON, Brasil. História das ruas do Rio. 5.ed. Rio de Janeiro: Lacerda Ed., 2000, p. 26-32; GORBERG, Samuel; FRIDMAN, Sergio. Mercados no Rio de Janeiro. 1834-1962. Rio de Janeiro: S. Gorberg. 2003, p. 2.

2 BICALHO, Maria Fernanda. A cidade e o Império: o Rio de Janeiro no século XVIII. Rio de Janeiro: Civilização Brasileira, 2003, p. 203-204; 220.

3 COARACY, Vivaldo. Memórias da cidade do Rio de Janeiro. 3.ed. Belo Horizonte; São Paulo: Itatiaia; Edusp, 1988, p. 60. Em 1638, a Câmara do Rio estabeleceu que os pescadores venderiam suas mercadorias no trecho que compreendia a Praia de Nossa Senhora do Carmo até a porta do Governador, ou seja, entre a atual Praça XV e a rua da Alfândega. Cf.: FRIDMAN, Sergio; GORBERG, Samuel, Op. Cit., p. 2.

4 Arquivo Geral da Cidade do Rio de Janeiro (doravante AGCRJ), Ofício da Secretaria de Estado de Negócios para o Senado da Câmara de 21/04/1823.

5 Cf.: FRIDMAN, Sergio; GORBERG, Samuel, Op. Cit., p. 12. COARACY, Vivaldo, Op. Cit.

6 Em 1836, quando os dois corpos do prédio voltados para o Largo do Paço ficaram prontos, seus compartimentos já começaram a ser alugados, gerando uma receita de 2:366\$500 réis. Com a crônica falta de recursos da Câmara, as obras da Praça só foram retomadas em 1839, sob o comando do engenheiro João Vicente Gomes. Finalmente concluídas em setembro de 1841, o custo total chegou a 170:396\$073 réis.

7 Desde sua construção até 1908 (quando o mercado foi demolido), essa estrutura básica da Praça do Mercado passaria por diversas reformas e acréscimos. E os trabalhadores, fossem locatários, pequenos lavradores, quitandeiras ou pombeiros, nem sempre concordavam com essas transformações. Em 1885, por exemplo, quando novas barracas foram construídas no cais das Marinhas, em substituição aos antigos chapéus de sol, os pequenos comerciantes já instalados naquela área recusaram-se a pagar a taxa exigida pelos empresários, que arrendaram o local e paralisaram suas atividades. Durante uma semana, a "greve das Marinhas" mobilizou vendedores de diferentes procedências, imprensa, vereadores e o próprio governo imperial. Para uma análise mais ampla desses protestos, ver: FARIAS, Juliana Barreto. “Mercado 
desembarcavam os gêneros da roça e o pescado que escravos e outros trabalhadores traziam em canoas de ganho, saveiros, faluas e barcos vindos das zonas suburbanas do Rio de Janeiro e das áreas rurais de Niterói. Bem próximo, lavradores, seus consignatários, negociantes e quitandeiras vendiam, revendiam e compravam "gêneros de primeira necessidade", como frutas, ovos, legumes e cereais, "sem o menor abrigo, apenas algumas pequenas barracas volantes ou algum chapéu de sol". ${ }^{8}$ E ainda havia os pombeiros (mercadores avulsos de peixe) que, apesar das proibições, atuavam como intermediários entre pescadores e consumidores.

Até o final da década de 1860, todas essas áreas de comércio estiveram sob a administração direta da Câmara Municipal do Rio. ${ }^{9}$ Em termos práticos, isso significava que qualquer alteração em sua estrutura, regulação sobre seu funcionamento ou demanda de diferentes categorias deviam ter apreciação e aprovação dos vereadores. Um deles era designado para ser o comissário do mercado e volta e meia formavam-se grupos para resolver assuntos específicos. Porém, no dia a dia, eles pouco frequentavam o lugar. Quem diariamente exercia "a rigorosa observância"das regras era o fiscal da freguesia da Candelária, também encarregado da inspeção cotidiana do mercado.

E ainda que o Regulamento apresentado na sessão da Câmara de 17 de novembro de 1843 e ratificado por portaria da Secretaria de Estado dos Negócios do Império em 16 de agosto de 1844 fosse o principal guia para sua ocupação e "boa administração", muitas questões não estavam previstas ali. Para resolvê-las, fiscais e membros da Câmara se valiam de novas posturas, avaliações ou votações, mas também recorriam a disposições e interesses que escapavam a qualquer formalidade. Isso era bem comum, por exemplo, no momento da concessão ou da transferência de uma vaga.

Neste artigo, vejamos mais de perto como tudo isso podia ocorrer. Para tanto, examinarei em detalhes as disputas travadas entre dois locatários da Praça - Domingos José Sayão, liberto africano de "nação calabar", e Antonio Joaquim Franco, "cidadão brasileiro" - pela posse de uma banca de peixe, em 1846. Num primeiro momento, buscarei avaliar quem estava "habilitado" a ocupar - e efetivamente ocupava - os diferentes espaços de venda no interior do mercado. Nesse percurso, também pretendo acompanhar as relações, igualmente diferenciadas, que esses pequenos negociantes mantinham com a municipalidade. Ao final, ainda será possível observar como esses processos acabavam revelando redes, interesses e particularidades que caracterizavam homens e mulheres de procedências tão diversas.

\section{Quem era "livre e capaz"?}

Se quisermos estabelecer uma hierarquia entre os trabalhadores da Praça, certamente os locatários das cento e doze bancas e casas internas, tais como

em greve: protestos e organização dos trabalhadores do pequeno comércio no Rio de Janeiro - Outubro, 1885". Anais da Biblioteca Nacional, 127, 2010, p. 99-157; Idem. "Greve nas Marinhas: protestos, tradições e identidades entre pequenos lavradores, quitandeiras e pombeiros (Rio de Janeiro, século XIX)". ArtCultura. Uberlândia, v.11, n.19, jul-dez. 2009, p. 35-55.

8 AGCRJ, Códice 61-2-17: Mercado da Candelária (1870-1879), p. 28.

9 Em 1869, a Praça foi arrendada, pelo prazo de nove anos, aos empresários Aureliano Dias da Costa Cabral e Antonio José da Silva, sob a firma Aureliano Cabral \& C. Abriam-se, assim, as portas para a entrada da iniciativa privada no mercado. E daí em diante elas não mais se fechariam. Embora esses novos administradores pudessem auferir grandes lucros com o aluguel de casas e bancas para antigos e novos locatários, a fiscalização do local e outros assuntos cotidianos continuavam a cargo da municipalidade. Mas isso estava longe de aplacar os conflitos — que pouco a pouco se tornaram uma constante — entre Câmara e empresários, empresários e pequenos comerciantes ou entre estes e os vereadores e fiscais. Para acompanhar os detalhes sobre esses arrendamentos, ver: FRIDMAN; GORBERG. Op. Cit., p. $23-32$. 
Sayão e Antonio Franco, ficarão em destaque. ${ }^{10}$ E não apenas porque apareciam como os principais autores de solicitações e petições enviadas quase diariamente à municipalidade, ou porque eram, a todo o momento, mencionados em descrições, avaliações e relatórios feitos por fiscais e vereadores. Durante boa parte do século XIX, eles desfrutaram de maior prestígio e poder na condução das vendas cotidianas, mesmo em relação a outras categorias profissionais. E, evidentemente, tudo isso era assegurado pela própria Câmara Municipal.

Mas nem todos podiam se tornar arrendatários. Embora os aluguéis não fossem proibitivos (e pudessem variar bastante de ano a ano ou de uma banca a outra), era necessário dispor de capital suficiente para montar - e sobretudo manter - os negócios. Afinal, para armar uma quitanda de verduras, frutas e aves, uma barraca de peixe ou um pequeno armazém de louças, precisavam de bancadas, tabuleiros, armações, estantes, mesas ou eventualmente alguns caixeiros ou serventes (muitas vezes escravos). E, sobretudo, fornecedores regulares. Para termos uma ideia de como os investimentos podiam ser elevados, vejamos os valores empregados numa sociedade entre cinco portugueses, estabelecida em 1867, para compra e venda de peixe salgado, cebolas, alhos e comissões em sete bancas da Praça. O capital da sociedade era de dezesseis contos e quinhentos mil réis, divididos entre os sócios. José Bessa Teixeira, por exemplo, entrava com quatro contos e trezentos mil, ao passo que Antonio Gonçalves Vieira e Antonio de Bessa Teixeira despenderam, cada um, dois contos e oitocentos mil. Com esses recursos totais, era possível comprar pelo menos dez escravas minas, que nessa época chegavam a valer de um conto a um conto e quinhentos mil réis. ${ }^{11}$

Além do mais, conforme o Regulamento de 1844, somente "pessoas livres e capazes" poderiam ocupar as vagas internas. À primeira vista, poderíamos supor que a condição de liberdade estivesse diretamente associada a indivíduos "brancos", fossem homens ou mulheres. De acordo com a historiadora Hebe Mattos, essa correlação persistiria no Sudeste escravista até pelo menos meados do século XIX, quando o crescimento de "negros e mestiços", livres ou libertos, já não permitia perceber os não brancos livres como exceções controladas. ${ }^{12} \mathrm{Na}$ Praça do Mercado, essa associação parece ter sido desfeita antes desse período. Ali, por livres, entendia-se não escravos. Mesmo que isso não estivesse explícito nas regras, outros registros - de autoria dos próprios vereadores - permitiram chegar a essa conclusão.

No final da década de 1830 , já se discutia na câmara municipal a redação das normas que integrariam o regimento do Mercado da Candelária. Num dos rascunhos, encontramos o $2 .^{\circ}$ artigo, justamente o que trata sobre as condições para habilitação dos arrendatários, com uma pequena — e reveladora — rasura. No meio do texto em que se definia que "o arrematante será pessoa livre e capaz, e que por si, seu sócio ou caixeiro esteja à testa do negócio”, o trecho “e nunca poderá alugar

10 Na caudalosa documentação sobre o mercado depositada no Arquivo Geral da Cidade do Rio de Janeiro, esses locatários também são identificados como arrendatários, inquilinos ou banqueiros. Neste artigo, privilegiarei essa categoria de trabalhadores da Praça, da qual fazia parte Domingos José Sayão e Antonio Franco. Já analisei outras categorias do mercado em: FARIAS, Juliana Barreto. "Entre pequenos lavradores e quitandeiras". Mercados minas: africanos ocidentais na Praça do Mercado do Rio de Janeiro (1830-1890). Tese (Doutorado em História Social). USP, 2012; Idem. "Pombeiros e o pequeno comércio no Rio de Janeiro do século XIX”. In: SOARES, Mariza de Carvalho; BEZERRA, Nielson Rosa. Escravidão africana no Recôncavo da Guanabara. Niterói: Editora da UFF, 2011.

11 AGCRJ, Códice 61-3-18: Comércio de peixe, pp. 6-8. Para os preços dos escravos, ver valores das alforrias pagas nesse período.

12 MATTOS, Hebe. Das cores do silêncio: os significados da liberdade do Sudeste escravista - Brasil, século XIX. 2.ed. Rio de Janeiro: Nova Fronteira, 1998. 
a banca a escravos" estava riscado. ${ }^{13}$ Por que eles não acharam necessário deixar no texto final a proibição aos cativos? E os libertos? Também estavam sendo considerados na genérica categoria de livres? De uma forma ou de outra, mesmo tentando ordenar aquele espaço de trocas, afastando os cativos dali (onde estavam desde princípios do Oitocentos, e até antes disso), eles não conseguiram alcançar seus intentos. Ao longo do século XIX, escravos continuariam vendendo quitandas e peixe nas bancas, como prepostos ou mesmo como subinquilinos dos arrendatários.

Por outro lado, as definições de uma pessoa "capaz" não eram tão evidentes assim. Consultando o Dicionário da Língua Portuguesa (1813), de Antonio de Moraes Silva, constatamos que o termo designava alguém "apto, hábil, suficiente em talentos; esforço; probidade; decoroso; decente". ${ }^{44}$ Luiz Maria da Silva Pinto também confere o mesmo significado no seu Dicionário da Língua Brasileira (1832): "suficiente em probidade; intentos, apto, decente". ${ }^{15}$ De que forma qualidades um tanto subjetivas poderiam ser provadas pelos interessados em uma vaga no mercado? No regulamento e em outros editais publicados posteriormente, não havia quaisquer informações nesse sentido. Para outras categorias até se exigiam registros e comprovação de habilitação em órgãos competentes. Os pescadores que ofereciam seus produtos nas canoas ancoradas no cais das Marinhas, por exemplo, deviam ter licenças e aprovação da Capitania do Porto. Ainda assim, muitos pombeiros conseguiam tirar essas autorizações sem estarem, segundo os fiscais da Praça, "capacitados" para a atividade.

No caso dos locatários, só uma parte remetia à Câmara Municipal pedidos mais detalhados. Sem um modelo obrigatório a seguir, a maioria praticamente apenas incluía nos requerimentos os seus nomes e o que pretendiam fazer nas bancas. É bem provável que muitos julgassem que as relações pessoais e o "reconhecimento profissional" que gozavam ali, afinal alguns comerciavam naquela área antes mesmo da construção do prédio do mercado, fossem garantias satisfatórias. E de fato as seleções deviam mesmo se valer dos interesses e das disposições e idiossincrasias de fiscais e vereadores.

Quando as solicitações chegavam à municipalidade, a vereança, que raramente tinha contatos mais diretos com o mercado e seus trabalhadores, encaminhava os documentos aos fiscais da Praça, para que estes avaliassem os pedidos e lhes fornecessem informações adicionais. De acordo com o Regulamento, esses agentes eram responsáveis pela "rigorosa observância" das regras, podendo empregar todos os meios que suas atribuições Ihes conferiam, autuando quem infringisse o regimento e outras posturas ou requisitando, se necessário, auxílio de força armada. Para os arrendatários e demais comerciantes do mercado - que diariamente viam os fiscais fazendo rondas, inspecionando mercadorias e ouvindo reclamações —, eles eram a expressão mais visível do poder municipal. ${ }^{16}$ Sendo assim, a aprovação de um pedido de locação e o reconhecimento da capacidade de um candidato dependiam, no final das contas, da rede de relações que ele mantinha na Praça - e

13 AGCRJ, Códice 61-1-20: Mercados (1820-1827), p. 21.

14 SILVA, Antonio de Moraes. Diccionario da Língua Portugueza - recompilado dos vocabularios impressos ate agora, e nesta segunda edição novamente emendado e muito acrescentado. Lisboa: Typographia Lacerdina, 1813, v.2, p. 466. Disponível em: http://www.brasiliana.usp.br/dicionario/2/capaz. Acessado em: 19 set. 2011.

15 PINTO, Luiz Maria da Silva. Diccionario da Língua Brasileira, por Luiz Maria da Silva Pinto, natural da Provincia de Goyaz. Typographia de Silva, 1832. Disponível em: http://www.brasiliana.usp.br/dicionario/3/ capaz Acessado em: 19 set. 2011.

16 Cf.: Regulamento da Praça do Mercado, apresentado em sessão da Câmara Municipal de 17 de novembro de 1843 e publicado em edital no dia 20 de agosto de 1844, transcrito em: FRIDMAN; GORBERG. Op. Cit., p. 14-23. Cf.: SOUZA, Juliana Teixeira. A autoridade municipal na Corte imperial: enfrentamento e negociações na regulação do comércio de gêneros (1840-1889). Tese (Doutorado em História). Unicamp, 2007. 
mesmo fora dela - e da avaliação, muitas vezes subjetiva e interessada, dos fiscais. Entretanto, para que tudo isso também ficasse claro para os vereadores, era preciso deixar registrado, formalmente, num papel.

Mas, se as apreciações das solicitações estavam mesmo sujeitas aos "olhares" dos fiscais e às relações construídas dentro e fora do ambiente de trabalho, por que os pretos forros - tão evidentemente mais próximos da escravidão quase não se autoidentificavam em seus registros, sobretudo quando comparados aos ditos "cidadãos brasileiros"? Pela Constituição de 1824, os libertos tinham seus direitos civis assegurados. Mas isso só valia para os que nascessem no Brasil. Os alforriados africanos não gozavam do mesmo status dos brasileiros e nem possuíam as garantias de estrangeiros protegidos por seus países de origem. ${ }^{17} \mathrm{No}$ dia a dia, ao menos que possuíssem uma prova em contrário, eles eram constantemente confundidos com escravos. Daí ser tão importante ter a comprovação de sua liberdade consignada em cartório e um atestado sempre à mão. ${ }^{18}$

No Mercado da Candelária, nenhum preto forro apresentou carta de alforria para ratificar sua condição de liberdade. Em geral, suas solicitações para locação das barracas ou renovação das licenças continham apenas seus nomes e o número das vagas pretendidas. Em 15 de dezembro de 1846, por exemplo, Emília Soares do Patrocínio, viúva de Bernardo Soares, pediu para "continuar com a banca na Praça do Mercado n. 96, pagar o semestre que corre de janeiro e passar-se os recibos em nome da suplicante visto que seu marido é falecido". No verso do documento, o fiscal Bernardino José de Souza anotou que tudo quanto Emília alegava era verdade e parecia ser o "caso de lhe passar em seu nome a banca no corrente semestre futuro". Dois dias depois, um comentário não assinado - certamente feito por algum vereador - confirmava o parecer do agente municipal. ${ }^{19}$ Emília Soares do Patrocínio permaneceu como locatária do mercado por quase 40 anos. E tanto ela como seu marido Bernardo eram "pretos forros" de "nação" mina. Mas Emília parece não ter considerado necessário incluir essa informação em seu requerimento. $E$ o fiscal também não fez qualquer questionamento nesse sentido. ${ }^{20}$

Já Matias José dos Santos, ao se candidatar à barraca 106 , "vaga por falecimento de um Francisco de tal" em janeiro de 1848, informou que era um "preto forro com negócio de verduras na Praça do Mercado". Em seu parecer, o fiscal André Mendes da Costa considerou que sua "pretensão não tinha lugar", porque o irmão — e sócio — do antigo arrendatário já pagara o semestre adiantado. Porém, Mathias não desistiu da locação e as discussões sobre o caso se estenderam na Câmara Municipal, chegando até a Secretaria dos Negócios do Império. Durante os debates, a condição social e a procedência de Mathias só foram mencionadas novamente em um requerimento do irmão do locatário, Francisco, que se referiu a ele como "o preto mina Matias José dos Santos". ${ }^{21}$

Apenas em alguns poucos casos os pretos forros se autoindentificavam dessa forma. Porém, quando se envolviam em disputas pela posse das bancas, muitas

17 Entre os poucos trabalhos que tratam do tema, destaco: MAMIGONIAN, Beatriz Galloti. "Razões de direito e considerações políticas: os direitos dos africanos no Brasil oitocentista em contexto atlântico". Texto apresentado no $5^{\circ}$ Encontro Escravidão e liberdade no Brasil meridional. Porto Alegre, maio 2011.

18 CUNHA, Manuela Carneiro da. Negros, estrangeiros: os escravos libertos e sua volta à África. São Paulo: Brasiliense, 1985, p. 76-89.

19 AGCRJ, Códice 61-2-2: Mercado da Candelária (1844-1849), p. 61.

20 Para mais detalhes sobre a trajetória da preta mina Emília, ver: FARIAS, Juliana Barreto. "De escrava a Dona: a trajetória da africana mina Emília Soares do Patrocínio no Rio de Janeiro do século XIX”. Revista Locus. UFJF, 2013.

21 AGCRJ, Códice 61-2-2: Mercado da Candelária (1844-1849), p. 107. Voltaremos ao caso da transferência dessa banca no próximo capítulo. 
vezes acabavam tendo o estatuto legal, a cor ou a "nação" africana revelados por seus oponentes. Foi o que também aconteceu com Vicente Antonio Francisco. Em 23 de outubro de 1855, o locatário Agostinho d'Almeida Figueiredo, procurador de Bernardina de Oliveira, tentou mais uma vez recuperar o arrendamento da banca 21, que pertencera ao finado Apolinário de Campos. Segundo Agostinho, desde novembro de 1850 apossara-se dela "o preto Vicente A. Francisco, que iludiu a Bernardina, viúva do dito Campos, dizendo que ia fazer a arrematação em nome dela". ${ }^{22}$ A contenda começara em janeiro daquele ano, mas em nenhum momento Vicente indicou sua cor ou seu status. Depois de várias negativas da Câmara Municipal, talvez Agostinho quisesse, ao chamá-lo de "preto", colocar em dúvida sua condição de liberdade e, em consequência, sua habilitação para ocupar uma vaga na Praça. Seja como for, o certo mesmo é que o fiscal da Praça e os vereadores não atentaram — ou não deram importância — para esse detalhe e a banca continuou com o "preto" Vicente.

Ao mesmo tempo em que Agostinho Figueiredo tentava destacar essa informação, "silenciava" a cor e a condição social de Bernardina Oliveira e de seu falecido marido nos requerimentos enviados à municipalidade em janeiro de 1855 . Só que os dados acabaram emergindo da documentação comprobatória anexada às petições. Na procuração passada a Agostinho, em abril de 1854, o tabelião classificou Bernardina como uma "preta livre". Já na certidão de casamento, celebrado na matriz de Santa Rita, em 21 de fevereiro de 1835, consta que ela era "filha natural de Marianna, preta de nação benguela, escrava que foi de Manuel d'Oliveira, natural e batizada nesta freguesia de Santa Rita". No mesmo documento, Apolinário de Campos é descrito como um "preto de nação mina", antigo escravo de Domingos de Campos, batizado na freguesia do Sacramento. Por sua vez, no registro de óbito assinado pelo escrivão da Irmandade de Santo Elesbão e Santa Efigênia, em março de 1849, ele aparece como "preto forro de nação de mina".23

Conforme veremos mais à frente, os pretos forros, sobretudo os africanos ocidentais, genericamente identificados como minas, com frequência pediam para continuar com o arrendamento das bancas que estavam em nome de cônjuges falecidos. E quando encaminhavam solicitações desse tipo, quase sempre incluíam assentos de óbito, batismo e casamento, testamentos e mesmo ações de divórcio. Para além da comprovação do vínculo matrimonial mantido com o antigo inquilino, esses registros ainda serviam para atestar sua habilitação às vagas. Afinal, na época, a condição civil de uma pessoa era legalmente decidida no registro paroquial, onde se encontravam livros de "livres" (incluindo-se aí também os libertos) e de "escravos". ${ }^{24}$

Embora esses novos candidatos - alguns nem tão novos assim, já que trabalhavam nas bancas junto com seus falecidos parceiros - apresentassem documentos que também certificavam sua capacidade para ocupar uma vaga na Praça, em geral, os alforriados africanos seguiam o padrão da maior parte dos arrendatários: encaminhavam pedidos concisos, indicando basicamente seus nomes e os lugares pretendidos. Como alguns vendiam suas quitandas naquela área antes mesmo da construção do prédio do mercado, talvez se valessem de um certo prestígio e do reconhecimento de fiscais e vereadores. E por isso mesmo não precisavam

22 AGCRJ, Códice 61-2-9: Mercado da Candelária (1855-1859), p. 24. [grifo meu]

23 Todos esses documentos foram anexados às petições encaminhadas em janeiro de 1855 e reunidas em: AGCRJ, Códice 61-2-9: Mercado da Candelária (1855-1859), p. 4-20.

24 Todos esses documentos foram anexados às petições encaminhadas em janeiro de 1855 e reunidas em: AGCRJ, Códice 61-2-9: Mercado da Candelária (1855-1859), p. 4-20. 
apresentar maiores informações sobre suas vidas. Quem sabe também a fama dos "pretos minas" como "exímios quitandeiros" fosse acionada - e percebida como uma espécie de garantia de suas aptidões. Quando Lauriana Maria da Conceição mencionava que era uma "mina", ao solicitar a aprovação de uma sociedade com Bernardino José Ribeiro, podia estar evidenciando com esse atributo um resumo de sua condição. Uma africana, não escrava, com "habilidade", "talento" para o comércio de verduras, legumes e frutas..$^{25}$ Da mesma forma que essas "qualidades" talvez estivessem sendo levadas em conta no momento em que o fiscal Bernardino José de Souza dizia saber, "por ver" ou "ter informações", que Emília e Bernardo Soares haviam sido casados e, enquanto "pretos minas", tinham "capacidade" para os negócios na Praça do Mercado.

No Rio de Janeiro Oitocentista, senhores de escravos, viajantes estrangeiros, políticos e, de resto, boa parte da população da cidade enfatizava essas "aptidões mercantis" de cativos e forros minas, especialmente quando comparados a africanos de outras "nações". ${ }^{26} \mathrm{Na}$ Praça, essas imagens e estereótipos também eram frequentemente evocados. Em 1865, a norte-americana Elizabeth Agassiz, por exemplo, acompanhava seu marido, o naturalista Luiz Agassiz, até o mercado do Rio,

\begin{abstract}
pelo prazer de ver os mostruários cobertos de laranjas, flores e legumes, e para observar os grupos pitorescos dos negros tagarelando ou vendendo suas mercadorias. Sabemos agora que esses negros atléticos, de rosto distinto e tipo mais nobre que os dos negros dos Estados Unidos, são os Minas, originários da Província de Mina na África ocidental. É uma raça possante, e as mulheres em particular têm formas muito belas e um porte quase nobre. Sinto sempre grande prazer em contemplá-las na rua ou no mercado, onde se vêem em grande número, pois as empregam mais como vendedoras de legumes e frutas que como criadas. ${ }^{27}$
\end{abstract}

O senador Hollanda Cavalcanti também dizia, na década de 1850, que bastava ir ao mercado de peixe, criação, frutas ou verduras da capital carioca "para se ver que a maior parte dos vendedores são libertos ostentando ainda as marcas tribais". ${ }^{28}$ Embora não mencione a procedência desses forros, certamente fiscais e outros frequentadores da Praça sabiam, somente "por ver", de quem se tratava. As "nações" dos africanos no Rio de Janeiro eram reconhecidas por muitos moradores e visitantes a partir de determinados signos, indumentárias e marcas corporais. Como ressalta a antropóloga Manuela Carneiro da Cunha, cada grupo podia dispor e manipular símbolos variados em diferentes contextos, mas, para que construísse, efetivamente, um padrão de identificação, eles tinham de ser inteligíveis a todos os demais. ${ }^{29}$

De qualquer maneira, essas breves referências ajudam a reforçar a hipótese de que o reconhecimento e os "olhares" de fiscais e outras autoridades eram determinantes para a habilitação de velhos e novos locatários da Praça. "Tomando

25 AGCRJ, Códice 61-2-7: Mercado da Candelária (1850-1854), p. 89. O pedido de Lauriana é de 16 de julho de 1852. Nesse documento, ela não informa a condição de Bernardino José Ribeiro.

26 Cf.: SELA, Eneida Maria Mercadante. Modos de ser em modos de ver: ciência e estética em registros de africanos por viajantes europeus (Rio de Janeiro, ca. 1808-1850). Tese (Doutorado em História). Unicamp, 2006.

27 AGASSIZ, Luiz; CARY, Elizabeth. Viagem ao Brasil. 1865-1866. Belo Horizonte: Ed. Itatiaia, 1975, p. 68.

28 Hudson a Palmerston, Rio de Janeiro, 27 jul. 1850, Encl. 2 in n. 85. apud CUNHA, Manuela Carneiro. Negros, estrangeiros. Op. Cit., p. 92.

29 CUNHA, Manuela Carneiro da. Antropologia do Brasil: mito, história e etnicidade. São Paulo: Brasiliense; Edusp, 1986, p. 94-95. 
conhecimento", "sabendo por ver” ou por ser "público e notório”, os agentes municipais identificavam quem estava apto ou não..$^{30}$ Como tantos habitantes do Rio, eles possivelmente também saberiam distinguir as "marcas tribais" dos vendedores libertos entrevistos pelo senador Hollanda Cavalcanti na década de 1850. Caso descobrissem - ou suspeitassem - que eram "pretos minas", poderiam associá-los às "habilidades mercantis" tão propaladas no próprio mercado e em outros locais da cidade, e mesmo em outras áreas do país. O que, por si só, já poderia ser suficiente para habilitá-los às vendas na Praça do Mercado.

\section{Nas bancas}

Entre todos os requerimentos sobre a ocupação das bancas que recolhi nos códices do Arquivo da Cidade, seja para ocupá-las pela primeira vez, seja para pedir a renovação das locações ou a transferência para terceiros, encontrei os seguintes termos usados para identificar os arrendatários (tanto por eles próprios como por funcionários municipais, vereadores e outros trabalhadores): "cidadão brasileiro" ou "brasileiro"; "preto forro", "preto de nação" e "preta livre"; "nação calabar", "preto mina", "mina” e "nação mina forra"; "natural d’Hispanha”; "português", "nacionalidade portuguesa" ou "súdito português". Como se vê, as expressões mencionadas por diferentes atores em momentos distintos e com objetivos diversos - indicavam nacionalidades (portuguesa, por exemplo), "nações" africanas (mina ou calabar) e ainda a combinação de condição social e nacionalidade, como o designativo "cidadão brasileiro".

Tomando como referência apenas esses documentos remetidos à Câmara Municipal por candidatos às bancas, locatários ou seus procuradores, poderia se concluir que esses grupos eram os principais — ou mesmo os únicos — que ocupavam as áreas internas da Praça do Mercado. No entanto, essas categorias muitas vezes obscureciam procedências, cores e condições. Assim, para dimensionar a composição étnica e social dos trabalhadores ali instalados, incorporei outras fontes à análise. Não foi possível seguir a trajetória de todos os arrendatários que passaram pelo mercado ao longo do século XIX. Ainda que os "brasileiros" tenham sido os que mais se autoidentificaram na documentação enviada à municipalidade, foram os que menos apareceram em outros tipos de registros. Já "portugueses" e "pretos forros" foram localizados em vários conjuntos documentais, tais como inventários, testamentos, ações de divórcio, registros de hipotecas ou cartas de alforria.

Para as décadas de 1830 e 1840, não dispomos de fontes regulares. O Almanak Laemmert — lançado em 1844 — só começou a divulgar listas completas de mercadores da Praça a partir de 1853. Entre a documentação da Câmara Municipal, apenas vez ou outra localizamos relações de locatários com os valores despendidos pelo aluguel das vagas. Em 1836, por exemplo, quando somente dois corpos do edifício voltados para o Largo do Paço haviam sido finalizados, uma "relação das pessoas" que "remataram as bancas do pescado" incluía os nomes de trinta e dois arrendatários, dos quais consegui identificar a origem de apenas cinco (dois africanos minas e três "brasileiros" ${ }^{31}$ ).

Confrontando essa listagem com um conjunto de licenças de 1831 e com outra lista divulgada em 1840, pude constatar que alguns pequenos comerciantes já

30 Esses termos eram constantemente usados pelos fiscais nos pareceres que enviavam à Câmara -

31 Usarei o termo "brasileiro" conforme indicado pelos próprios locatários. Em alguns casos, acrescentarei os locais de naturalidade, de acordo com o informado nas fontes. 
estavam instalados ali antes mesmo da construção da Praça, e continuariam se destacando nos anos subsequentes à sua inauguração. Entre os registros de 1831, encontramos Domingos José Sayão, identificado como "preto forro" de "nação calabar", compartilhando a banca 31 com Francisco do Espírito Santo, de quem não sabemos a procedência. Sayão permaneceria na Praça até o ano de 1870 (completando 39 anos no local). Junto com eles estavam ainda dois serventes: José Ganguela e Anacleto crioulo. Possivelmente, ambos eram escravos.

Desde as primeiras décadas do século XIX, era comum que africanos - em geral cativos - auxiliassem os vendedores nas barracas montadas na Praia do Peixe. ${ }^{32}$ Porém, já nessa época, a presença dos escravos incomodava alguns banqueiros. Em 1836, eles enviaram uma petição à Câmara Municipal, reclamando que, nas arrematações anteriores, a posse e o uso das bancas haviam sido transferidos a "pessoas que não são daquela profissão e comércio", incluindo-se aí muitos "homens escravos". O que trazia "gravíssimo prejuízo aos banqueiros de boa fé, em especialmente aqueles que têm a propriedade de seus vasos, redes, escravos e mais utensílios de pescaria". Sendo assim, pediam que somente fossem aceitos como novos arrematantes "pessoas da própria profissão e nunca negociantes e pessoas das diferentes repartições". 33

Mas os escravos nem sempre eram obstáculos. Num abaixo-assinado de dezembro de 1840, 16 arrendatários no "Mercado do peixe" (entre os quais quatro "cidadãos brasileiros" e um português) diziam que, "sendo notório quão laborioso é um tal tráfico", necessitavam de serventes que se sujeitassem "ao árduo e desagradável serviço indispensável à venda do pescado, o que não pode ser feito, geralmente falando, por pessoas livres, que exigirão extraordinários e onerosos ordenados, encarecendo deste modo o preço de um gênero de primeira necessidade". ${ }^{34}$

De um lado, os banqueiros queixavam-se da existência de cativos à frente das bancas. Por outro, pediam à Câmara que os deixassem ter mais serventes e caixeiros - de preferência escravos, já que os livres exigiriam "onerosos ordenados". Toda essa discussão, é certo, não escapou aos vereadores. Em 1844, na hora de redigir as normas do mercado, eles procuraram uma espécie de conciliação. Ao mesmo tempo em que só admitiam locatários "livres e capazes", permitiam que os escravos pernoitassem nas bancas e casas, desde que seus senhores ficassem responsáveis por eles e entregassem ao fiscal uma lista com seus nomes e de quem mais fosse permanecer ali. ${ }^{35}$ Entretanto, durante o dia, os "pretos de ganho" estavam proibidos de andar dentro da Praça. E os cativos que fossem mandados por seus donos para fazer compras não deviam demorar "além do tempo necessário para efetuá-las". Quanto isso representava exatamente, eles não disseram. De qualquer forma, essa medida decerto era uma tentativa de coibir a ação de "pretos cativos atravessadores", que causavam "graves inconvenientes e prejuízos" aos locatários, chegando o "escândalo ao ponto de já não ser quase possível hoje a um cidadão o poder empregar-se neste gênero de indústria comercial sem se expor a continuados insultos e comprometimentos". ${ }^{36}$

Só que a questão não parecia tão simples assim. Em geral, esses atravessadores - que revendiam o pescado a preços mais elevados — atuavam como pre-

32 AGCRJ, Códice 61-3-13: Comércio de peixe (1831), pp. 39 e 43.

33 AGCRJ, Códice 61-1-21: Mercado da Candelária (1832-1839), p. 48.

34 AGCRJ, Códice 61-3-15: Comércio de peixe (1840-1848), p. 2.

35 "Regulamento da Praça do Mercado...", citado em Mercados no Rio de Janeiro, p. 20. Entre os códices sobre o mercado, guardados no Arquivo da Cidade, não encontrei essas listas mencionadas no Regulamento.

36 AGCRJ, Códice 61-3-15: Comércio de peixe (1840-1848), p. 6. As queixas estavam num abaixo-assinado enviado à Câmara em dezembro de 1847, por cinco arrematantes das bancas de peixe da Praça do Mercado. 
postos de seus senhores, que, muitas vezes, eram também arrendatários da Praça. Apesar da vigilância constante de fiscais e vereadores, muitos conseguiam driblálos, ou mesmo contar com sua conivência. Ao longo do século XIX, os agentes municipais que presidiam comissões fiscalizadoras constantemente apontavam essas irregularidades, sem, contudo, eliminá-las de vez. Por isso, as listas de mercadores divulgadas pelo Almanak a cada início de ano não correspondiam, necessariamente, aos vendedores que as ocupavam de fato. Em 1865, de um total de 112, 48 (ou seja, um terço) estavam sublocadas "sem o consentimento da Ilma. Câmara", ou tinham "figurando no negócio pessoas diversas". ${ }^{37}$ Ainda assim, como esse fenômeno - apesar de recorrente - não era generalizado, podemos tomar essas relações como ponto de partida para uma análise mais sistemática da composição étnica e social dos arrendatários que, se não de forma efetiva, ao menos nominalmente, estavam ali instalados. ${ }^{38}$

Percorrendo o interior do mercado, especialmente entre as décadas de 1840 e 1870 , constatamos que vendedores de diferentes gêneros tendiam a persistir por longos períodos em suas bancas. Às vezes, ficavam de posse de dois ou mais lugares em uma mesma área ou em pontos diferentes do Mercado da Candelária. Mesmo que não tenha sido possível avaliar a proporção de todos os inquilinos conforme suas origens, consegui estimar que, naquele período, os portugueses estavam presentes em todas as áreas. Os africanos, e especialmente os minas, concentravam-se nas vendas de legumes, verduras, aves e ovos. E os brasileiros ficavam mais nos negócios com pescado. Ainda que, por vezes, os minas estivessem, de fato, nas bancas alugadas em nome de portugueses. Ou estes, nas de brasileiros. E assim por diante.

Vejamos, por exemplo, a distribuição nas 30 bancas do centro (de números 79 a 112), destinadas ao comércio de hortaliças, legumes, aves e ovos. Em 1853, havia 29 mercadores registrados no Almanak, dos quais reconheci a procedência de 23 (cerca de 79\%): oito portugueses; nove africanos minas; um africano Angola e quatro brasileiros. Como podemos perceber, esse pedaço era uma espécie de reduto dos africanos da Praça. Na banca 96, a mina Emília Soares do Patrocínio dava continuidade aos negócios abertos em 1840 por seu primeiro marido, o também mina Bernardo Soares. Logo ao lado, na vaga 95, sua amiga Antonia Rosa, preta forra da mesma "nação", também seguia com as vendas iniciadas por seu marido, o preto mina Januário Francisco de Mello. Quando Antonia deixou o local, em 1865, o mina Joaquim Manuel Pereira, segundo marido de Emília, tornou-se o novo inquilino, e ficou ali por mais de 20 anos. Para completar, a preta mina ainda firmou uma sociedade com Feliciana, africana da mesma "nação". Ex-cativa do crioulo Antonio José de Santa Rosa, Feliciana trabalhara com seu senhor na banca 98 por pelo menos seis anos. Em 1846, com a morte de Santa Rosa, ela ganhou sua carta de alforria. E não hesitou em solicitar a posse da quitanda, onde labutou sozinha durante cinco anos. De 1852 a 1857, dividiu as vendas com Emília. Com o fim da sociedade, esta última manteve-se na barraca até 1885 .

Seguindo pelo mesmo corredor, encontramos, lado a lado, diversos "pretos forros". Na banca 100, Maria Alexandrina Rosa, de "nação" Angola, vendeu suas quitandas entre os anos de 1853 e 1859. Depois de passar para Joaquim José Leite \& C. (de 1859-1862), a vaga foi ocupada pelo preto mina Amaro José de Mesquita até 1869. Já a mina Maria Rosa da Conceição ficou por 20 anos (de 1840 a 1860) nas

38 Para acompanhar uma análise mais detalhada dos locatários de todas as áreas internas da Praça do Mercado do Rio, ver o capítulo 2 de minha tese, “Entre locatários e quitandeiras”. In: Mercados minas. Op. Cit. 
bancas 102 e 103. Mais adiante, estavam mais africanos e africanas minas: Lauriana Maria da Conceição (104: de 1852 a 1858); Matias José dos Santos (106: de 1847 a 1858); Luiz Laville (107: 1859 a 1870) e João José Barbosa (108: 1842 a 1865).

E os portugueses também compartilhavam essa área do mercado. Nas relações do Almanak, o imigrante José Maria de Paula Ramos é citado em 1844 como um dos "principais mercadores". Natural de Coimbra, ele chegara ao Rio de Janeiro dois anos antes, com 35 anos de idade. Ao se registrar em 1842, afirmou que tinha a ocupação de negociante e morava na Praça do Mercado, número 84. Até 1858 , ele esteve à frente dessa banca. E ainda arrendou outras duas ( 83 e 85 ) para negociar os mesmos gêneros. Depois de sua morte, em 1859, o português Antonio Maria de Paula Ramos, seu filho e genro do locatário Bonifácio José da Costa, instalou-se em seu lugar. Nas imediações, outro conterrâneo, o luso José da Costa e Souza, contava com duas locações. Entre os anos de 1856 e 1870, manteve sociedade na banca 89 com a preta mina Felicidade. E na 109, com a quitandeira Josefa, no período de 1854 a 1870. À semelhança dos africanos minas, alguns negociantes de Portugal, como o próprio José Souza, também chegavam a somar de 10 a 20 anos de Praça.

Uma estratégia que parecia generalizada era a transferência das bancas entre locatários de igual procedência ou de uma mesma família. Quando um imigrante luso falecia, seu filho ou um conterrâneo o substituía. Ao saírem, os minas também davam lugar a outros africanos da mesma "nação". Aparentemente semelhantes, essas práticas podiam guardar especificidades para cada grupo. A formação de sociedades entre indivíduos de mesma procedência era igualmente recorrente. Mesmo assim, não faltavam parcerias entre portugueses e brasileiros; africanos e brasileiros ou portugueses e minas. Ao contrário do que ocorria em outras partes da cidade, estes dois últimos grupos não estavam permanentemente em conflito. ${ }^{39}$

Nas bancas internas da Praça do Mercado (e em outras de suas áreas), as relações diárias entre eles envolviam concorrência e rixas, das corriqueiras às mais "sérias". Ainda assim, rivalidades e conflitos não eram o "comportamento padrão" na Praça. Desde as primeiras décadas do Oitocentos, pretos minas montavam sociedades comerciais com imigrantes de Portugal e até mesmo realizavam parcerias para comprar escravos. Como boa parte dos africanos não sabia ler e escrever, negociantes portugueses assinavam, em seus nomes, abaixo-assinados e petições. E ainda atuavam como testemunhas em seus processos de divórcio. Não obstante, homens e mulheres da Costa da Mina preferiam labutar junto com seus "parentes de nação". Do mesmo modo que os arrendatários de Portugal associavam-se a irmãos, primos e compadres europeus. Como se vê, o trabalho e a convivência diária entre eles poderiam ser bem mais complexos, incluindo tanto aproximações como diferenças e hierarquias.

\section{Transferências}

Assim que as bancas do mercado vagavam — seja por desistência ou falecimento do locatário —, sócios, amigos, herdeiros, cônjuges e outros parentes não

39 Cf.: ALENCASTRO, Luiz Felipe de. "Proletários e escravos: imigrantes portugueses e cativos africanos no Rio de Janeiro, 1850-1872”. Novos Estudos Cebrap, n.21, jul. 1988, p. 30-56; RIBEIRO, Gladys Sabina. A liberdade em construção: identidade nacional e conflitos antilustianos no Primeiro Reinado. Rio de Janeiro: Relume Dumará, 2003. 
demoravam a ocupar seus lugares. Só que essas transferências por vezes acabavam rendendo muita discussão. Especialmente porque não havia, no Regulamento de 1844 , uma postura muito bem definida sobre o assunto. Como recorrentemente acontecia ali, as decisões sobre quem seriam os novos inquilinos também dependiam das circunstâncias, dos interesses e das personagens envolvidas. A história de Domingos José Sayão, preto forro de nação calabar, ilustra, de muitas maneiras, essas questões.

Em 17 de novembro de 1846, ele enviou um requerimento à Câmara Municipal, pedindo para continuar na banca 23, já que seu sócio Joaquim de Souza acabara de falecer. No verso do documento, o fiscal Bernardino José de Souza confirmou a informação. Logo em seguida, foi a vez do vereador Tristão Ramos da Silva aprovar a solicitação. Alguns dias antes, o "cidadão brasileiro" Antonio Joaquim Franco também havia requerido a ocupação da vaga. Nesse caso, porém, Bernardino indeferiu o pedido, justificando que Domingos, como antigo parceiro de Joaquim, já estava de posse do lugar. ${ }^{40}$

Mas a seleção ainda não estava encerrada. Embora, normalmente, apenas o vereador encarregado da Praça do Mercado confirmasse — ou refutasse - as avaliações dos fiscais, a decisão sobre a ocupação dessa vaga foi levada à votação no plenário da Câmara. Em 24 de novembro, o vereador José de Silveira Pilar dizia concordar com o parecer de Ramos da Silva e decidira apresentar suas razões. Em primeiro lugar, era incontestável que Sayão e Antonio haviam sido sócios. Sendo assim, por "vigorosa justiça" e pela "boa conduta" que sempre manteve, ele devia continuar no local. No entanto, mesmo com todas as deliberações a seu favor e as negativas ao pedido de Antonio Franco, essas informações foram desprezadas, e isso poderia "ser qualificado na opinião pública como um patronato escandaloso". E prosseguia, destacando que

o referido Saião, um infeliz preto, sócio e representante de um homem cego, qual o falecido Joaquim de Souza, não tendo por si pessoa alguma que por ele falasse, tendo aliás muitas que se interessavam por Franco, o que é público e notório e foi declarado na discussão pelo dito Vereador Ramos da Silva, pode geralmente acreditar-se que na Câmara Municipal só se consegue as coisas por empenhos e não pelos princípios da razão e da justiça. ${ }^{41}$

Para finalizar, fazia questão de lembrar que esta era a primeira vez que a municipalidade agia dessa forma:

expelindo por falecimento do locatário o sócio do mesmo, que o requereu e obteve as melhores informações, para dar a um indivíduo de fora, ao qual nenhum direito assistia, e a quem se podia dar uma das duas que se acham vagas, ou qualquer das que tem de vagar no fim de dezembro. Por tudo isso, muitos acreditariam que a instituição servira de instrumento de vingança, cometendo de mais uma violência, uma iniquidade. ${ }^{42}$

Acompanhando o vai e vem de petições e pareceres nos códices municipais conservados no Arquivo da Cidade do Rio de Janeiro, não localizei qualquer ofício

40 Cf.: AGCRJ, Códice 61-2-2: Mercado da Candelária (1844-1849), p. 51 (requerimento de Domingos José Sayão); Códice 61-3-15: Comércio de peixe (1840-1848), p. 59-59v.

41 AGCRJ, Códice 61-2-2: Mercado da Candelária (1844-1849), p. 52. [grifo meu]

42 AGCRJ, Códice 61-2-2: Mercado da Candelária (1844-1849), p. 52. 
atestando a concessão da banca a Antonio. Ainda assim, as palavras de Silveira Pilar não deixam dúvidas de que o concorrente de Domingos Sayão conseguira reverter a situação. Mais especificamente na sessão do dia 24 de outubro, a municipalidade escolhera Antonio Franco como novo locatário. ${ }^{43}$ Só que isso, como se vê, também não representou o fim das disputas. Por volta do dia 10 de dezembro, Sayão decidiu tentar recuperar a vaga, dessa vez dirigindo-se ao governo imperial. De acordo com o recurso do artigo 73 da lei de $1 .^{\circ}$ de outubro de 1828 , incluso no regimento das Câmaras, os "cidadãos residentes na Corte" que se sentissem agravados pelas deliberações, acordos e posturas das Câmaras Municipais podiam recorrer, na defesa de seus interesses, à Assembleia Geral Legislativa e ao Ministério dos Negócios do Império, contanto que a matéria fosse meramente econômica e administrativa. ${ }^{44}$

Acontece que libertos africanos como Domingos José Sayão não eram, como vimos, considerados "cidadãos" no Império brasileiro. Nem por isso eles deixavam de pedir proteção ao Ministério ou mesmo diretamente ao imperador. Entre os papéis da Câmara sob a guarda do Arquivo da Cidade, não encontrei a petição de Sayão. Contudo, em 10 de dezembro, um ofício encaminhado à instituição pelo gabinete ministerial mencionava o documento e solicitava mais informações sobre o caso. Antes de os vereadores apresentarem uma resposta, o "preto forro" Ihes remeteu mais um requerimento, informando que, por se sentir "ferido em seus mais lícitos direitos", solicitara proteção da "Imperial Justiça e Bondade de S. M. I. [Sua Majestade Imperial]". E dessa feita tratava de apresentar os mesmos motivos expostos naquela súplica, para que as autoridades municipais se "dignassem a resolver a questão". Além de indicar que fora sócio de Joaquim Souza durante 11 anos, recordava o "exemplo que se praticou com Joaquim José Maria", também "preto forro", de "nação" mina. Na "qualidade de sócio de um locatário falecido", ele havia sido "considerado na mesma banca, não obstante a apresentação de um novo pretendente, no que deu certamente a llustríssima Câmara uma prova de sua retidão e justiça". ${ }^{45}$

Sayão não apresentava muitas informações novas, mas sua petição mais uma vez provocou discussões entre os membros da instituição camarária. O primeiro a se manifestar foi Joaquim Vicente Torres Homem. Antes de explicar a decisão tomada na sessão de 24 de novembro, achava necessário expor alguns esclarecimentos que fundamentaram aquela resolução. Para ele, era notório - e "infelizmente sabido" - que há muito tempo havia se fixado no mercado um "tão escandaloso abuso no transpasse das bancas sem o consentimento da Câmara", que nem todas as medidas tomadas em diferentes administrações foram suficientes para coibi-lo. No ano anterior, sócios de uma banca tiveram que entregar "avultadas luvas" a certos indivíduos para se apoderarem de suas vagas. Nas vendas de pescado, alguns arrendatários as sublocavam a três ou quatro atravessadores, que passavam a oferecer os gêneros em grupos diferentes. A "convenção entre eles era tal" que os consumidores, por necessidade, acabavam se sujeitando aos altos preços estabelecidos. E certamente todas as infrações eram de conhecimento dos fiscais ou então se valiam de sua negligência. Disso tudo, resultava o seguinte:

43 A informação consta de um documento enviado pelo Ministério dos Negócios do Império em 10 de dezembro de 1848. Ver em: AGCRJ, Códice 61-3-15: Comércio de peixe (1840-1848), p. 61

44 Brasil. Lei de $1 .^{\circ}$ de outubro de 1828, sobre o regimento das Câmaras Municipais do Império, art. 73. Citado em: SOUZA, Juliana Teixeira. A autoridade municipal na Corte imperial. Op. Cit., p. 34.

45 AGCRJ, Códice 61-2-2: Mercado da Candelária (1844-1849), p. 62. 
Quando o arrendatário de qualquer banca quer se retirar do negócio, recebe de um desses atravessadores luvas, declarando à Câmara que ele era sócio e consequentemente a ser preferido a outro qualquer, declarando esta que não sendo acompanhada de documento comprobatório, em nenhum caso pode ser considerada como valiosa, e que, pelo contrário, deve ser rejeitada pelo conhecimento que tem a Câmara de semelhantes abusos. ${ }^{46}$

Para Torres Homem, esse era justamente o caso de Domingos Sayão. Como não apresentara qualquer registro para atestar sua sociedade com o falecido Joaquim de Souza, ele não teria o "menor direito" à banca. No "estado em que as coisas existem na Praça do Mercado", uma informação passada por um vizinho, que "comercia o mesmo gênero e quer especular da mesma maneira", também só podia ser suspeita. Sendo assim, o melhor, na opinião do vereador, seria responder ao governo que Sayão não apresentava título algum. Pelo contrário: devia ser considerado como "intruso", em consequência de todas as irregularidades relatadas. Por outro lado, de acordo com os dados apurados (pessoalmente?), fora possível confirmar que Antonio Joaquim Franco era "homem capaz e com proporções de se estabelecer naquela praça sem cometer abuso de sublocar a atravessadores parte de sua banca, com prejuízos do público". 47

Nem todos os vereadores tinham a mesma opinião. Ao comentar o parecer de Joaquim Torres Homem, um outro tribuno, cuja assinatura não consegui decifrar, considerava "pouco exato o que nele se diz em geral a respeito de passagens de bancas" e das providências tomadas pela municipalidade. Além disso, já estava "plenamente provado que o dito Sayão era sócio de Joaquim Souza". Sua convicção baseava-se nas evidências apresentadas pelo fiscal e pelo vereador encarregado da Praça, cujas conclusões haviam sido confirmadas pelas "pessoas mais acreditadas" do mercado. Mas também se reportava a outras fontes. Como podiam certificar os empregados da Tesouraria da Câmara, era "público e notório" que, no "tempo em que vivia o cego Souza", Sayão sempre ia pagar o aluguel da banca 23, sozinho ou em sua companhia. E, de acordo com o vereador Filgueiras, os próprios herdeiros de Souza reconheceram no "preto forro" a qualidade de sócio de seu falecido parente. Nenhum deles tinha qualquer intenção de assumir seus negócios, "antes deixando a Sayão na mansa e pacífica posse e no livre direito de continuar só nos semestres futuros".

Dessa forma, não havia “interesse ou conveniência alguma” em expulsá-lo dali, para colocar um "indivíduo de fora, a quem com quanto se façam elogios prévios"; não se podia "pôr acima daquele que, já experimentado, tem em seu favor as melhores informações de muitas pessoas e de autoridades em quem a Câmara tem obrigação de acreditar". Finalmente, lembrava mais uma "razão mui poderosa": em junho de 1845, na ocasião de aumentar o aluguel das bancas, todos concordaram, por unanimidade, em manter os locatários pelo prazo de quatro anos, com o valor inicial que fora marcado. Por isso mesmo, conforme a lotação de 1845 , Sayão tinha de ser conservado no seu local, não podendo ser "expelido sem que à Câmara falte a obrigação que contraíra". ${ }^{48}$

Apesar de mais este voto favorável ao "preto forro", a sentença da vereança não sofreu qualquer modificação. Em 22 de dezembro de 1846, um ofício foi enviado ao Conselheiro Joaquim Marcelino de Brito, Ministro e Secretário de Estado

46 AGCRJ, Códice 61-3-15: Comércio de peixe (1840-1848), p. 62.

47 AGCRJ, Códice 61-3-15: Comércio de peixe (1840-1848), p. 62.

48 Idem. 
dos Negócios do Império, confirmando a decisão da sessão de 24 de novembro e reproduzindo algumas palavras de Torres Homem. Não obstante, ainda não seria dessa vez que Domingos Sayão ficaria de fora da Praça. Em 26 de março de 1847, ele pediu uma nova licença para vender peixe fresco e salgado na banca 55 . À sua sucinta solicitação, o agente municipal responsável também deu uma breve resposta: concedida. ${ }^{49}$ Nenhuma menção ao atribulado episódio de meses anteriores. No final das contas, contrariando as razões apontadas por Joaquim Torres Homem, quem se revelou um verdadeiro especulador foi Antonio Joaquim Franco.

Quase um ano após a contenda com Sayão, o fiscal André Mendes da Costa encontrou, na banca alugada a Franco, um indivíduo de nome José Fortunato, oferecendo peixe ao público pelo miúdo, sem ser consignatário de pescador ou arrendatário do local. Quando intimado a retirar-se dali, ele respondeu que fora convidado pelo dono, "o qual lhe assegurou que pessoa alguma seria capaz de o fazer sair do lugar em que estava". De imediato, Fortunato foi detido pelo fiscal, que acabou "injuriado" por Antonio Franco, "com maneiras indecentes e grosseiras". Por isso, o locatário também foi levado preso. Os autos da apreensão foram enviados ao Chefe de Polícia e André da Costa rogou aos vereadores que não deixassem "impune um escândalo tão revoltante"..$^{50}$ Infelizmente, não achei outros registros que elucidassem o final dessa história. Voltando aos embates entre Franco e Sayão, talvez possamos esboçar algumas explicações.

\section{Um "patronato escandaloso"?}

Logo no início das discussões na Câmara, o vereador-presidente José Silveira Pilar afirmara que até então nenhuma transferência havia sido decidida pela municipalidade de maneira tão arbitrária. De fato, ao examinar a documentação sobre o mercado nas décadas de 1830 e 1840, não me deparei, pelo menos até o ano de 1846, com situações que gerassem tamanho debate. O caso de Sayão foi tão emblemático que, em 1848, serviu como referência - a não ser seguida - em outra disputa pela posse de uma banca, também envolvendo um forro africano, o mina Matias José dos Santos. ${ }^{51}$ Entretanto, se o desenrolar do pedido aparentemente corriqueiro de Domingos Sayão surgia como uma "novidade", as práticas que permearam boa parte das avaliações subsequentes não eram tão inéditas assim.

Mais uma vez, o discurso de Silveira Pilar nos fornece evidências nesse sentido. Avaliando a conduta da vereança diante das solicitações de Sayão, ele mencionava um "patronato escandaloso". Como o "preto forro" não tinha "pessoa alguma que por ele falasse, tendo aliás muitas que se interessavam por Franco", a "opinião pública" poderia acreditar que, na Câmara, "só se consegue as coisas por empenho e não pelos princípios da justiça". Por certo, essas apreensões não se fundamentavam apenas no caso em questão. Ainda que fiscais e vereadores

49 AGCRJ, Códice 61-3-15: Comércio de peixe (1840-1848), p. 70.

50 AGCRJ, Códice 61-2-2: Mercado da Candelária (1844-1849), p. 73. No documento, o fiscal também pedia que a Câmara colocasse em execução o $1 .^{\circ}$ artigo do Regulamento da Praça, onde se determinava que, "no caso de alguém não cumprir ou fazer pouco caso das ordens que lhe forem intimadas pelo respectivo fiscal, ou for turbulento, o mesmo Fiscal Ihe intimará incontinente o despejo da banca, Ihe sendo restituída a quantia correspondente ao tempo que faltar para o complemento do arrendamento". Ver: Regulamento da Praça do Mercado.., citado em: FRIDMAN; GORBERG. Op. Cit., p. 14.

51 Os requerimentos e pareceres sobre o caso do mina Matias estão em: AGCRJ, Códice 61-2-2: Mercado da Candelária (1844-1849), p. 92-94; 99-100, 107-111; 113. Mais adiante, voltarei a tratar de alguns pontos dessa discussão. 
constantemente se referissem ao Regulamento da Praça do Mercado como ponto de partida para as suas resoluções, muitas situações e possibilidades não eram previstas ali. Nessas circunstâncias, outros critérios e interesses eram levados em conta, como, por exemplo, a intervenção dos chamados "protetores".

Em momentos diversos, locatários, quitandeiras, fiscais e outros agentes municipais faziam referências - quase sempre indeterminadas - a redes de proteção que se ramificavam por todas as áreas do mercado e chegavam, também por vias incertas, à Câmara Municipal. Como eram interditas, revelavam-se muito mais em situações de conflito ou por meio de "denúncias" daqueles que não contavam com tal amparo. Em novembro de 1846, por exemplo, a ex-escrava mina Feliciana de Santa Rosa tentava arrendar as bancas 97 e 98, que haviam pertencido a seu antigo senhor, o "crioulo" Antonio José de Santa Rosa. Mas, como ela assinalava, já existiam outros pretendentes "com muitas proteções". De onde elas vinham exatamente, quase ninguém informava. Talvez fossem representadas por vereadores, fiscais ou os próprios arrendatários, como o português José da Costa e Souza, que dizia ter duas escravas como suas "protegidas" nas vagas alugadas em seu nome. Aliás, em muitas situações, os imigrantes lusos ainda podiam contar com o apoio - efetivo e legal - do Consulado de Portugal.

Mas muito raramente se falava sobre as maneiras pelas quais essas "proteções" eram acionadas. Não obstante, nas entrelinhas de discursos, avaliações e até de alguns requerimentos bem concisos, é possível perceber que elas se enquadravam numa espécie de "economia de concessão e favores". Em troca da "proteção" da vereança, alguns locatários, especialmente aqueles que tinham mais recursos, ofertavam joias ou mesmo faziam barganhas eleitorais. Quanto maiores fossem o "reconhecimento" do inquilino e as "vantagens oferecidas aos cofres" da municipalidade, maior seria a "ajuda" recebida. Porém, não eram somente os trabalhadores do mercado que agiam assim.

Segundo a historiadora Juliana Teixeira Souza, os comerciantes varejistas do Rio de Janeiro oitocentista também estavam habituados a oferecer donativos em troca de benefícios que só poderiam ser conferidos pelo poder constituído. Para tanto, recorriam a uma prática consagrada no Antigo Regime e largamente utilizada no jogo político entre o rei e seus vassalos. Contudo, existiam diferenças fundamentais entre as estratégias que vigoravam no século XVIII e as das primeiras décadas do Oitocentos. Nestas, o objetivo essencial não era empreender qualquer modificação na conduta social, mas sim assegurar a manutenção da margem de lucro nos negócios e a acumulação de capital. A busca incessante por prestígio dava lugar à tentativa de obter maiores vantagens pecuniárias. Com efeito, os diversos grupos que atuavam nas vendas a varejo pareciam compartilhar a certeza de que mereciam maior proteção da Câmara os munícipes que pagassem os tributos mais pesados..$^{52}$

No Mercado da Candelária, esses artifícios e as redes oblíquas que os envolviam nem sempre eram explicitados. Só mesmo em ocasiões bem específicas. A transferência de arrendatários nas bancas era uma delas. O fenômeno, no entanto, não era novo. Ao menos desde a década de 1830, banqueiros, fiscais e vereadores reclamavam dos seguidos repasses feitos sem o consentimento da Câmara. E por diversas vezes foram ensaiadas tentativas - muitas em vão - para impedi-los.

Ceder a posse e o uso das bancas não era proibido. O que não se permitia era passá-las a terceiros por conta própria. Ou seja, o inquilino que quisesse fazer a transferência para outro comerciante deveria informar, por escrito, sua intenção

52 SOUZA, Juliana Teixeira. A autoridade municipal na Corte imperial. Op. Cit., p. 173. 
à Câmara Municipal, solicitando também que os recibos do aluguel fossem lançados em nome do novo ocupante. Os valores cobrados permaneceriam os mesmos. Acontece, porém, que muitos não avisavam à municipalidade e continuavam passando suas bancas sem serem incomodados. E ainda estipulavam valores mais altos, para assim garantir seu lucro. De tal forma que alguns arrendatários, constantemente referidos como especuladores, formavam verdadeiros monopólios. Tudo isso à vista - e decerto com a anuência — dos fiscais, que diariamente deviam fazer rondas na Praça para assegurar o cumprimento do regulamento.

Em julho de 1865, como o problema ainda persistia, a Câmara resolveu nomear um vereador para investigar o assunto pessoalmente. No relatório apresentado logo em seguida, o Dr. Bezerra constatou que as irregularidades encontradas ali eram reflexos diretos da "benevolência" da municipalidade "para com vários especuladores que dispõem da Praça como de sua propriedade, e outros da negligência dos fiscais até hoje encarregados da polícia daquele estabelecimento pela falta de seus deveres". ${ }^{33}$ Conforme constatou, todas as 112 bancas estavam arrendadas, "ou antes ocupadas". Algumas, subarrendadas sem a aprovação da Câmara. Outras mantinham à frente do negócio pessoas com o título de gerentes ou administradores. Após percorrer as diferentes áreas do mercado e inquirir seus ocupantes, o encarregado municipal concluíra que

A série de abusos e defeitos de sua administração, devidos à falta de execução de seu regulamento, assim como o prejuízo causado às rendas da municipalidade pelo sistema de lotação das bancas até hoje seguido, abusos que redundam todos em prejuízo do público, por isso que concentrado em mãos de meia dúzia de homens, por homens privilegiados [...]. Daqui resulta a indeclinável necessidade em que está a llustríssima Câmara de tomar algumas medidas que reprimam tais abusos, e façam conhecer aos especuladores e monopolistas da Praça do Mercado, que ela não está disposta a tolerar mais tanto escândalo [...].54

Como resultado mais imediato às suas enfáticas palavras, os vereadores lançaram um edital com novas posturas, a fim de melhorar a fiscalização das praças do mercado e das marinhas. Para começar, intimavam todos os indivíduos que estavam nas bancas, sem serem seus locatários, a apresentarem, no prazo de oito dias, os títulos de posse e as autorizações ou procurações dos verdadeiros inquilinos. Quem não mostrasse "título legítimo" podia legalizar sua situação, desde que se sujeitasse às condições exigidas e aos mesmos preços que a Câmara cobrava naquele momento. Todos esses "novos" arrendatários - e também os antigos que ainda não o tivessem feito - deviam apresentar "fiadores idôneos". De outra parte, aqueles que pretendiam retirar-se do Império ou do negócio deviam, igualmente, comunicar à municipalidade, indicando quem ocuparia o lugar a partir de então. No caso de falecimento dos atuais inquilinos, os "favores até hoje concedidos aos sucessores" só seriam feitos quando eles fossem maiores de idade. Caso contrário, a liquidação da casa e a arrecadação (ou arrematação) dos bens seriam reclamadas em juízo competente, e o local posto em lotação novamente. ${ }^{55}$ Imediatamente após o lançamento dessas medidas, muitos trabalhadores enviaram

53 AGCRJ, Códice 61-2-11: Mercado da Candelária (1865), p. 9.

54 Idem.

55 O edital foi publicado no dia 4 de julho de 1865 e anunciava oito medidas: as seis primeiras eram relativas à regulação da ocupação das bancas internas e as duas últimas versavam sobre o comércio de peixe dentro e fora do mercado. Para conferir o documento completo, ver: AGCRJ, Códice 61-2-12: Mercado da Candelária (1866-1867), p. 175. 
requerimentos e os respectivos comprovantes para a regularização perante a Câmara. Entretanto, a longo prazo, tudo isso não se mostrou suficiente para debelar o problema.

Das avaliações de Bezerra também emergiram os nomes dos principais "especuladores e monopolistas da Praça”. À frente da lista estava o português José da Costa e Souza. Com as informações apuradas in loco, o vereador concluíra que o imigrante, também conhecido pelo apelido de José da Lenha, era, "por assim dizer, o verdadeiro dono da Praça do Mercado". Como exercia bastante "influência" e "poderio" sobre a maior parte dos banqueiros, muitos tinham certeza de que ele podia fazer tudo quanto pretendesse. Bastava olhar para as atenções que a Câmara lhe dispensava, concedendo-lhe qualquer banca que quisesse locar ou arrendar por sua própria conta.

"Frequentemente zombando" do Edital de 20 de agosto de 1844, como enfatiza o vereador em seu relatório, este "homem notável nos fatos da história" do mercado, "para o qual tem havido sempre tanta benevolência", era locatário - e também tinha "debaixo de diversas pessoas" - 13 bancas, correspondente a mais de 1/10 do total das vagas ali existentes. Segundo os cálculos feitos pelo agente municipal, elas estavam assim divididas: peixe (banca 13); cereais (50 e 52); gelo (86 e 87 ) e verduras $(88,89$ e 109). Além dessas, também dispunha, como procurador, das de números 91, 102 e 103. Não satisfeito com isso, também solicitara a posse de mais dois lugares e, por resolução da Câmara Municipal em 31 de dezembro de 1864 , Ihe foram concedidas as bancas 24 e $77 .{ }^{56} \mathrm{O}$ fato de possuir tantos locais e ainda manter, em dois deles, depósitos de gelo, o que era expressamente contrário às disposições do regulamento, só revelava seu "pouco caso" com as regras da Praça e a "proteção que parece ter até hoje merecido da Câmara".57

Só que a atuação deste "dono do mercado" ia além. Seguindo sua trajetória ao longo dos 30 anos (de 1840 a 1870) em que ficou ali, constatei que o português fazia e desfazia sociedades com seus conterrâneos e com comerciantes de outras procedências (entre os quais forros africanos e até mesmo escravas), afiançava novos locatários, figurava como inventariante e testemunha em processos diversos, formava parcerias com outros arrendatários para compra de novos cativos, emprestava dinheiro a juros e ainda assinava petições a rogo daqueles que não sabiam ler e escrever, incluindo-se aí boa parte dos pretos minas.

Sem dúvida, José da Costa e Souza desfrutava de muitas "proteções" no Mercado da Candelária e, sobretudo, na Câmara Municipal. Senão, como explicar que, mesmo após as acusações divulgadas no relatório de Bezerra e a publicação do edital de 4 de julho de 1865 , ele ainda tenha sido indicado como fiador por muitos arrendatários, sem que fiscais e vereadores esboçassem qualquer objeção? Pelo contrário, ele era descrito nos pareceres então emitidos como um "reconhecido locatário" da Praça, que gozava de probidade e "todo conceito no comércio" do Rio de Janeiro..$^{8}$

56 AGCRJ, Códice 61-2-11: Mercado da Candelária (1865),p. 11-12.

57 Como completa Bezerra, "este abuso, porém, seria tolerável se o depósito de gelo não fosse instituído com fins especulativos e prejudiciais aos interesses econômicos e do povo, e à saúde pública, por quanto ninguém desconhece que esse depósito é principalmente destinado para guardar o peixe que, em virtude do alto preço que por ele exigem, não se vende em um dia, para o vender no dia seguinte ou mesmo depois, infringindo assim, em detrimento da saúde pública, o artigo 16 do citado regulamento, que terminantemente dispõe que o peixe não pode ser guardado de um dia para o outro senão salgado". AGCRJ, Códice 61-2-11: Mercado da Candelária (1865), p. 11-12.

58 No Códice 61-2-12: Mercado da Candelária(1866-1867), há diversos requerimentos enviados à municipalidade após a divulgação do edital de 7 de julho de 1865. Em boa parte deles, José da Costa e Souza aparece como 
Caso esbocemos uma espécie de hierarquia dos trabalhadores mais influentes da Praça, Costa e Souza decerto ocuparia o topo, usando e abusando de suas bancas e contando, para isso, com o amparo de poderosos - e supostamente invisíveis - protetores. Já indivíduos como o "cidadão brasileiro" Antonio Joaquim Franco, embora menos protegidos que o imigrante português, também tinham muitos que se "interessavam" por eles. No outro extremo, apareciam aqueles que não possuíam "por si pessoa alguma”, ou nenhuma tão influente, para falar em seu nome. Nesse grupo, estaria o liberto Domingos José Sayão.

Não tenho muitas informações sobre a vida de Sayão. Nos requerimentos enviados à Câmara, ele se identificava como um "preto forro" de "nação calabar". A expressão fazia referência a dois portos da baía de Biafra (na atual Nigéria): VeIho Calabar e Novo Calabar. Em diferentes registros oitocentistas, escravos e libertos dessa "nação" constituíam uma minoria entre os africanos ocidentais que viviam no Rio de Janeiro. E nunca eram designados conforme seus grupos étnicos. Entretanto, sob o genérico termo, certamente estavam homens e mulheres dos grupos ibos, mokos, efiks ou ibibios. ${ }^{59} \mathrm{~A}$ partir dos documentos disponíveis, inferi que Sayão nascera por volta do ano de 1790 e, desde a década de 1830, já vivia no Rio de Janeiro. ${ }^{60}$ Mas não pude precisar quando e como exatamente chegara à capital carioca. Ou tampouco sobre o tempo em que permaneceu como escravo. Ainda assim, é possível afirmar que ele rapidamente se inseriu na comunidade de africanos minas da cidade.

Além de trabalhar lado a lado com eles na Praça do Mercado, desde 1841 pertencia à Irmandade de Santo Elesbão e Santa Efigênia, congregação católica criada pelos minas no século XVIII, que também reunia outros locatários africanos. ${ }^{61}$ Como um dos comerciantes mais longevos do mercado, ele construiu importantes relações de amizade e de prestígio entre "os seus" ${ }^{62}$ (como indica o cargo de juiz de Santa Efigênia que ocupou na irmandade em diferentes anos compromissais ${ }^{63}$ )

fiador de muitos locatários, inclusive de forros minas. Na mesma época, o português Antonio Maria de Paula também afiançou vários arrendatários.

59 Cf.: KARASCH, Mary. A vida dos escravos no Rio de Janeiro (1808-1850). São Paulo: Companhia das Letras, 2000, p. 65-66; BEZERRA, Nielson Rosa. Mosaicos da escravidão: identidades africanas e conexões atlânticas do Recôncavo da Guanabara (1780-1840). Tese (Doutorado em História), UFF, 2010, p. 165-170.

60 Em 28 de fevereiro de 1871, o Diário do Rio de Janeiro informou em seu obituário o falecimento de Domingos José Sayão: "africano, 80 anos, viúvo, febre perniciosa [a causa do óbito]".

61 Arquivo da Irmandade de Santo Elesbão e Santa Efigênia (doravante AISESE). Registros de Entrada de Irmãos (1843-1900). Documentação sem catalogação. Nesse livro, Domingos aparece registrado em 1844, mas, ao final, foi acrescentada a informação de que o registro era de 12 de agosto de 1841 e vinha do "livro velho de 1768". Além dessas indicações, só mais uma foi anotada: a data de seu falecimento, 20 de fevereiro de 1871. Outras informações sobre a participação de Domingos na irmandade também podem ser consultadas no Livro de Atas da ISESE - 1857-1926. Documentação sem catalogação.

62 Cf.: OLIVEIRA, Maria Inês Côrtes de. "Viver e morrer no meio dos seus. Nações e comunidades africanas na Bahia do século XIX”. Revista USP, São Paulo, n.28, dez. 1995 e fev, 1996.

63 Nas eleições anuais para os cargos da mesa diretora da irmandade, os juízes eram, geralmente, escolhidos entre aqueles de maior posse, reputação e importância social em sua comunidade. Afinal, eles contribuiriam com esmolas, por vezes de valores consideráveis, e ainda teriam de preparar a festa dos oragos. Durante essas comemorações anuais, as confrarias promoviam a confraternização e o fortalecimento dos laços entre os irmãos e destes com seus santos. Celebrá-los solenemente era uma garantia de proteção na vida e na morte. Quanto mais espetacular fosse a homenagem, maior seria a retribuição dada a seus devotados fiéis. Além disso, essas ocasiões também serviam para testar o prestígio da devoção e de seus juízes. OLIVEIRA, Anderson José Machado de. Devoção negra: santos pretos e catequese no Brasil Colonial. Rio de Janeiro: Quartet; FAPERJ, 2008, p. 264-265. 
e também com fiscais e mesmo com alguns vereadores. Mas, conforme acompanhamos, ele decerto não tinha "defensores" tão poderosos (ou mais que os de Antonio Franco) na Câmara Municipal.

Não à toa, decidiu buscar apoio na "Justiça e Bondade de Sua Majestade Imperial". Nada mais adequado do que recorrer à principal autoridade do "mundo do governo" para arbitrar aquela disputa. Entre as muitas "obrigações" do imperador, estava o dever de zelar pela paz, pela defesa e pelo proveito de todos os seus súditos. Segundo Ilmar de Mattos, isso lhe outorgava o "monopólio da responsabilidade", cuja contrapartida era a submissão de todos. ${ }^{64}$ Ao se valer dos rituais de deferência ao imperador, ainda comuns em petições desse tipo, certamente Sayão também pretendia reforçar a ideia de que, melhor do que qualquer outro agente do governo atuando em nome da lei (e no seu caso, eles estavam agindo além da lei), era a autoridade imperial quem detinha a faculdade de julgar conforme o direito e a melhor consciência.

A popularidade de d. Pedro II era alta entre os negros - escravos ou forros — da cidade do Rio, que viam o soberano como árbitro imparcial na justiça e protetor maior "dos fracos e oprimidos". ${ }^{65}$ Aliás, essa percepção já se fazia sentir desde o século XVIII. Como mostra o historiador Russell-Wood, durante o período colonial, africanos que viviam em Salvador, Recife e no Rio de Janeiro — e também em outras possessões portuguesas - costumavam servir-se deste meio extrajudicial, levando seus casos diretamente ao monarca ou aos mais altos representantes da Coroa. Para os vassalos destituídos de meios financeiros, ou cuja condição social os relegava para as ínfimas camadas da sociedade, sem relações influentes ou acesso à máquina judiciária, esse mecanismo era fundamental, pois transcendia a possibilidade de evitar magistrados indiferentes ou insensíveis e uma burocracia inacessível e muitas vezes corrupta. Segundo Russell-Wood, era o único caminho para uma forma de justiça privada que operava independentemente das leis escritas, dos canais legais e da magistratura e que, no espírito popular, era função de uma interpretação personalizada da monarquia. ${ }^{66}$

Ainda que com intenções, caminhos e resultados diferenciados, essa crença ainda persistiria entre os "pretos" do Rio até os últimos anos da monarquia, inclusive entre os comerciantes do Mercado da Candelária. Em outubro de 1885, durante a greve que paralisou as atividades na Praça das Marinhas, uma quitandeira negra apareceu recorrendo a D. Obá, o descendente de africano tido como "príncipe do povo" das ruas da cidade, para que ele, por meio de seus artigos constantemente publicados na imprensa, escrevesse ao imperador para tentar angariar apoio a seu protesto. ${ }^{67}$

64 Cf.: MATTOS, Ilmar Rohloff de. O tempo saquarema: a formação do Estado imperial. São Paulo: Hucitec, 2004, p. 161-163. SOUZA, Juliana Teixeira. A autoridade municipal na Corte imperial. Op. Cit., p. 190.

65 Cf.: REIS, João José. “Quilombos e revoltas escravas no Brasil”. Revista USP. São Paulo, 1996, n.28, p. 11; SCHWARCZ, Lilia Moritz. As barbas do imperador: d. Pedro II, um monarca nos trópicos. 2.ed. São Paulo: Companhia das Letras, 2008, p. 15-22.

66 RUSSELL-WOOD, J. R. "Vassalo e soberano: apelos extrajudiciais de africanos e indivíduos de origem africana na América portuguesa". In: SILVA, Maria Beatriz Nizza da (coord.). Cultura portuguesa na terra de Santa Cruz. Lisboa: Editorial Estampa, 1995, p. 215-233.

67 Trata-se da representação - uma espécie de charge publicada no jornal ilustrado O Mequetrefe, de 10 de outubro de 1885, e intitulada "O que é ser príncipe" - do encontro de uma quitandeira negra, com seu tabuleiro de frutas, com o Príncipe D. Obá (identificado pelos seus trajes elegantes, reproduzidos em diversas ilustrações do período). Entre eles, trava-se o seguinte diálogo: “- Abença?...Home, esse greve! Um!...tá bão... Vossucê percisa fazê o escrevê a imperadô, desse cosa q si chama ballaquinha que tá lá na Plaça. /-Oh!...vai acabar. Já tenho alguns artigos prontos!” Para uma análise mais detalhada dessa imagem, ver: FARIAS, Juliana Barreto. "Mercado em greve: protestos e organização dos trabalhadores do pequeno comércio no Rio de Janeiro Outubro, 1885”. Op. Cit., p. 140-141. Sobre o Príncipe D. Obá, ver: SILVA, Eduardo. Dom Obá II D’África, o Príncipe do Povo. Vida, tempo e pensamento de um homem livre de cor. São Paulo: Companhia das Letras, 2001. 
Seja como for, segundo Juliana Teixeira Souza, teoricamente, não cabia ao governo central julgar o mérito ou a oportunidade das resoluções tomadas pela municipalidade, mas tão somente impedir que os vereadores infringissem as leis gerais as quais deviam se ajustar. Não obstante, as deliberações pendentes de aprovação ou sanção das autoridades superiores à Câmara eram tantas - e de tal forma indefinidas - , que o resultado final acabava comprometendo a autonomia municipal, mesmo em temas exclusivos à administração local. ${ }^{68} \mathrm{Na}$ disputa entre Sayão e Franco, a decisão da vereança foi reafirmada pelo governo imperial sem maiores discussões. Certamente influências subterrâneas, inclusive denunciadas por alguns vereadores, foram bem determinantes. No entanto, o fato de Domingos Sayão não possuir documentos escritos que comprovassem sua sociedade na banca conferiu um caráter legal à resolução.

É certo que no regulamento de 1844 , ou mesmo nas posturas que se seguiram, não existia qualquer determinação nesse sentido. Contudo, fiscais e agentes municipais afirmavam que, "como era sabido", "sempre que há sociedade, há escritura pública, ou papel de trato particular”. Na falta deles, podiam até lançar mão de depoimentos fidedignos ou de investigações in loco. Mas eles nem sempre eram encarados como garantias. Em 1848, Francisco da Cunha, cuja procedência não consegui identificar, disputava a posse da banca $106 \mathrm{com}$ o mina Matias dos Santos, asseverando que era parceiro do antigo locatário (seu próprio irmão) que acabara de falecer. Como não tinha registros que atestassem a dita sociedade, ele remeteu à Câmara um abaixo-assinado por cinco indivíduos que a confirmavam. Porém, para o fiscal da Praça, o documento não era "suficiente para fazer valer ser um indivíduo sócio de outro, e desgraçados dos negociantes se semelhante argumento fosse valioso, porque esta forma assim que qualquer que falecesse se improvisam sociedades em nome dos falecidos". 69

Nesse ponto, os africanos - especialmente os solteiros — já partiam, de antemão, em desvantagem. Bem diferente dos "cidadãos brasileiros" e, sobretudo dos portugueses, eles não costumavam registrar suas parcerias em cartórios ou mesmo estabelecer contratos sociais. Nos diferentes acervos documentais em que pesquisei, só localizei um único acordo escrito, firmado entre um africano mina e outro locatário, de quem não foi possível saber a origem. Em $1 .^{\circ}$ de março de 1849, o mina Jerônimo José Rodrigues e Francisco Pereira da Rosa contrataram uma sociedade na banca 18 , pelo período de um ano, mediante algumas condições. Enquanto Jerônimo entrava com a posse e as benfeitorias do lugar, Pereira fornecia os fundos que fossem precisos, atuando como caixa e gerente da sociedade. E ainda "obrigava-se" a conceder a Rodrigues a quantia de trezentos e quarenta mil réis de lucro durante aquele prazo, mesmo se tivessem algum prejuízo.70

Outros "pretos forros" até encaminhavam ofícios informando fiscais e vereadores sobre a existência - ou o desmonte - de suas sociedades. Mas não costumavam registrá-las em cartório. Geralmente, os negócios de africanos e africanas baseavam-se na confiança, na palavra empenhada, muito mais difíceis de constatar. Como a maior parte não sabia ler e escrever, e por isso dependia de outros que o fizessem (quase sempre os próprios locatários da Praça, especialmente os portugueses), os acertos orais feitos entre os parceiros de trabalho acabavam ganhando foro de contrato equivalente àqueles escritos e assinados em cartório. ${ }^{71}$

68 SOUZA, Juliana Teixeira. A autoridade municipal na Corte imperial. Op. Cit., p. 31

69 AGCRJ, Códice 61-2-2: Mercado da Candelária (1844-1849), p. 90-91.

70 Idem, p. 153.

71 É uma situação de alguma forma semelhante ao que acontecia nas juntas de alforria que unia africanos em Salvador, conforme analisado em: REIS, João J. Domingos Sodré, um sacerdote africano: escravidão, liberdade e candomblé na Bahia do século XIX. São Paulo: Companhia das Letras, 2008, p. 210-211. 
Contudo, para a municipalidade, acordos desse tipo não eram suficientes para certificar a existência de sociedades, sobretudo quando se tratava de transferir a posse das bancas. Como então explicar que - afora Domingos Sayão e Matias dos Santos, que se envolveram em demoradas disputas - a maior parte dos "pretos forros" associados permanecesse por longos períodos numa mesma banca e ainda transferisse a vaga para parentes e cônjuges de sua "nação"?

Uma eficiente rede de informações estava permanentemente em funcionamento no Mercado da Candelária. Não por acaso, assim que um local ficava disponível, parceiros de trabalho, parentes, amigos e outros pretendentes mais próximos, de posse da informação, corriam para pleitear a vaga na Câmara, antes mesmo que um leilão público fosse aberto, oferecendo lances tidos como mais vantajosos. Além do mais, boa parte desses africanos estava no mercado há muito tempo (alguns instalados ali antes da construção do seu prédio) e gozava "de muita reputação" e "boa estima" no lugar, o que era confirmado tanto por outros arrendatários como por alguns fiscais e vereadores. Entretanto, tal reconhecimento não valia apenas para esses libertos africanos. Novos e antigos banqueiros portugueses e "brasileiros" também eram aprovados quase que imediatamente em função do "bom conceito" que desfrutavam ali e na própria cidade do Rio de Janeiro. Mas os "pretos forros" - e, em especial, os minas - ainda contavam com uma particularidade a seu favor.

Enquanto os imigrantes lusos estavam habituados a estabelecer sociedades formais em suas vendas primordialmente com conterrâneos homens, com quem tinham algum parentesco consanguíneo (filhos, primos ou irmãos), os minas não registravam seus contratos de parcerias, mas trabalhavam lado a lado com homens e mulheres da mesma procedência (os chamados "parentes de nação"), quase sempre seus próprios cônjuges. Em geral, apenas um deles (mais frequentemente, os homens) aparecia como titular da vaga e se colocava à frente das petições e demais documentos encaminhados à municipalidade. Mas — na labuta cotidiana - as atividades eram divididas entre os dois. O que, por certo, não escapava aos agentes da fiscalização e a outros trabalhadores da Praça. Talvez por isso, na hora em que o locatário inscrito deixava a sociedade - geralmente por falecimento - , o pedido feito pelo companheiro (ou companheira) para continuar nos negócios era aprovado de forma automática. Nessas ocasiões, eles enfim apresentavam documentos comprobatórios. Não eram registros em cartórios atestando as relações comerciais, mas certidões de casamento, óbito, batismo ou testamentos. Será que, aos olhos dos avaliadores municipais, essas "provas" de suas uniões matrimoniais também equivaliam a comprovantes de suas parcerias profissionais?

Se a argumentação delineada até aqui não nos convence de todo, ao menos é possível afirmar com segurança que essa prática costumeira, demandada preferencialmente pelos minas, acabou virando uma regra no mercado, afixada em edital de 30 de outubro de 1855, garantindo assim que cônjuges e filhos tivessem a preferência no arrendamento das bancas de inquilinos falecidos. De meados da década de 1840 até a publicação dessa nova postura, não achei, como era de se prever, portugueses ou portuguesas solicitando os lugares ocupados anteriormente por seus companheiros. Entre os "cidadãos brasileiros", apenas uma viúva desejava permanecer nos negócios iniciados pelo falecido marido. Já para os pretos minas, localizei cinco casos desse tipo. A história do casal Luiz Laville e Felicidade Maria da Conceição, dois forros dessa "nação", é bem exemplar. Em novembro de 1851, Laville dirigiu uma súplica aos vereadores, onde dizia que 
sendo casado com Felicidade Maria da Conceição (hoje falecida), como prova pelo documento junto, e tendo o suplicante arrendado em nome da dita mulher a banca número 41 da Praça do Mercado, acontece que sendo o suplicante falto de um braço, e tendo cinco filhos menores para alimentá-los e não tendo outro modo de vida se não o pequeno negócio de quitanda de verduras na dita banca, vem por isso o suplicante implorar as Vossas Senhorias a graça de lhe conceder a continuação do arrendamento da mesma banca em seu nome portanto. ${ }^{72}$

De acordo com o fiscal Antonio Joaquim de Mello, todas as informações apresentadas eram verdadeiras, mas - "sendo as transferências expressamente proibidas" - só a Câmara poderia despachar favoravelmente, "se assim o entender". O vereador encarregado da Praça compreendeu que a proibição, na qual se fundara o fiscal, não podia ser extensiva ao caso, já que o "requerente [era] marido/como prova/ da falecida locatária da banca em questão e vivendo em harmonia e sendo ele de fato o dono do negócio, entendo se fará justiça, deferindo-se a sua pretensão".

E assim foi feito. Laville permaneceu na banca 51 até 1858 . No ano seguinte, mudou-se para a de número 107, onde ficou instalado por mais 11 anos. De suas declarações, e também das do vereador, depreendemos que, apesar do primeiro lugar estar em nome de Felicidade, ele era o verdadeiro "dono do negócio". Talvez fosse apenas mais um modo de reforçar o papel masculino, já que, à época, o homem era considerado o "cabeça do casal". O certo mesmo é que, como apresentou "provas" de sua condição (o assento de óbito de Felicidade, no qual constava ser casada com o "preto mina"), Laville conseguiu a aprovação de seu pedido.

A partir de 1855, com a normatização desse mecanismo, outros pretos minas e também portugueses e brasileiros passaram a usá-lo com regularidade, incluindo-se aí - como previsto na postura — filhos e herdeiros dos antigos locatários. É claro que esses processos não ficaram destituídos de conflitos. Ou tiveram sempre o mesmo desenrolar e igual continuidade. De qualquer forma, no caso dos minas, essas práticas mais uma vez evidenciavam a importância do trabalho entre "parentes de nação". E como tudo isso também estava diretamente relacionado às suas vivências cotidianas em outros espaços sociais.

Embora se dispusesse de um regulamento específico para a Praça do Mercado (ratificado em 1844), e constantemente fossem aprovados - e colocados em prática - novos editais e normas, as decisões municipais sobre diferentes demandas dos trabalhadores ali instalados muitas vezes dependiam de motivações e resoluções que escapavam às formalidades legais. Como vimos, aqueles que desfrutavam de maior proteção, fosse de fiscais da Praça, vereadores ou dos próprios comerciantes do mercado, tinham suas reivindicações - ou até os pedidos mais simples - logo satisfeitas. De outro lado, também não era difícil encontrar escravos - cujos senhores podiam trabalhar no mercado ou não — vendendo gêneros em diferentes bancas ou apenas comprando produtos, apesar das diferentes proibições nesse sentido. Bem mais complexos do que um primeiro olhar poderia sugerir, esses processos em geral envolviam redes de interesse, solidariedades, contatos e proteções em geral indeterminadas.

72 AGCRJ, Códice 61-2-7: Mercado da Candelária (1850-1857), p. 78. 
Além do mais, a experiência de trabalho no local, em muitos casos, anterior à construção do mercado, e o reconhecimento de uma certa "aptidão mercantil" pareciam igualmente fundamentais nas avaliações, em especial quando estava em jogo a concessão de uma vaga ou a aprovação de uma transferência. E isso conseguimos acompanhar a partir das trajetórias de alguns pretos minas. Não obstante se tratasse de africanos libertos, e, portanto, mais próximos da escravidão, eles praticamente não tiveram suas "habilidades" para o ofício ou sua condição de liberdade questionada por agentes municipais ou pela vereança.

Mas essas constatações não podem ofuscar, é certo, a agência dos próprios trabalhadores da Praça. Conforme também observamos, locatários ou candidatos a uma vaga, assim como quitandeiras e pombeiros ocupados em outras áreas do mercado, embora muitas vezes partissem de interesses e objetivos distintos (e por que não conflitantes), valiam-se de diferentes dispositivos e estratégias para garantir o que consideravam "justo" ou um "direito". Nesse caminho, podiam ir longe e chegar ao imperador, como o fez o calabar Domingos José Sayão. Adotar posturas coletivas, como constatamos a partir da profusão de abaixo-assinados e petições conjuntas encaminhados à Câmara, e hoje compilados nos muitos códices do Arquivo da Cidade do Rio de Janeiro. Ou, no limite, organizar uma greve, como aconteceu em outubro de 1885. De um jeito ou de outro, ao final, podiam conseguir que práticas e direitos costumeiros fossem ratificados pela Câmara e incorporados aos regulamentos da Praça do Mercado. 
